\title{
The Characteristics of Riparian Buffer Studies
}

\author{
K. S. Shearer ${ }^{*}$ and W. N. Xiang \\ Department of Geography and Earth Sciences, University of North Carolina at Charlotte, Charlotte, NC 28223, USA
}

\begin{abstract}
Riparian buffers are vegetated areas along water bodies that serve an array of functions, ranging from water quality protection, soil erosion control, to species preservation. The establishment and maintenance of riparian buffers have been an important environmental management practice in the United States since the 1970's. Emerging along with this practice is a body of knowledge about riparian buffers. In this article, over 500 articles published in the past three decades are reviewed, substantiating this still evolving field of inquiry, which we shall designate as riparian buffer studies. Among the major findings of the literature review are (1) the literature starts to emerge with greater frequency in the 1980's, grows in depth and scope throughout the 1990's, and continues to the present date; (2) publications surveyed fall into three broad thematic categories that relate to the functions, performance, and policies of riparian buffers, respectively; (3) a large percentage of the publications (over 80\%) address issues across thematic categories; (4) this convergence of thematic categories may suggest not only the interwoven nature of the various aspects of riparian buffers, but also the need for a holistic approach to riparian buffer studies; (5) geospatial information technology plays an integral role in the evolution of riparian buffer studies; (6) emerging themes for riparian buffer studies include optimization of benefits, wildlife research, ecosystem restoration, headwater stream functions, economics, restoration, performance, policy, active management, and disturbance ecology, just to name a few.
\end{abstract}

Keywords: A holistic approach, buffer function, buffer performance, buffer policy, geospatial information technology, optimization of buffer benefits, riparian buffers, riparian buffer studies

\section{Introduction}

Riparian buffers are vegetated areas along water bodies that serve an array of functions (Hairston-Strang and Adams, 2000; Swanson et al., 1982), ranging from water quality protection (Carpenter et al., 1998), soil erosion control (Bilby, 1984), wildlife preservation (Boulet et al., 2003), to regulatory setbacks between certain human activities and a water body (Payne et al., 1988). The establishment and maintenance of riparian buffers have been an important environmental management practice in the United States since the 1970's (Xiang, 1993a,b).

Emerging along with this practice is a body of knowledge about various aspects of riparian buffers, which we shall designate as riparian buffer studies. Drawing upon scholarly contributions from a wide spectrum of academic fields - forestry, geography, botany, economy, political science, hydrology, to name just a few, the literature of riparian buffer studies is cross-disciplinary in nature. This is evidenced by the literature's distribution among a wide array of scholarly journals (a partial list can be found at the end of this article). Although reviews of the literature that focuses on a specific area of riparian buffer studies are beneficial (Correll, 2005; Wenger, 1999), thus far, a comprehensive review that systematically examines the characteristics and evolution of this body of knowledge across disciplines has yet to be conducted. Not only will a review of this caliber present a holistic picture of this

\footnotetext{
* Corresponding author: kshearer@ci.charlotte.nc.us
}

still emerging area of scientific investigation, but it can also cultivate the development of a sustainable approach that seeks a balance among economical, social and environmental goals in the practice.

This article is intended to serve these purposes. Through an in-depth literature review of over 500 articles from the past three decades that substantiate the riparian buffer studies ${ }^{1}$, it reveals the following characterizations of riparian buffer studies. (1) The literature starts to emerge with greater frequency in the 1980's, grows in depth and scope throughout the 1990's, and continues to the present date. (2) Publications surveyed fall into three broad thematic categories that relate to the functions, performance, and policies of riparian buffers, respectively. (3) A large percentage of the publications (over 80\%) address issues across thematic categories; and (4) this convergence of thematic categories may suggest not only the interwoven nature of the various aspects of riparian buffers, but also the need for a holistic approach to riparian buffer studies. (5) Geospatial information technology plays an integral role in the evolution of riparian buffer studies. (6) Emerging themes for riparian buffer studies include optimization of benefits, wildlife research, ecosystem restoration, headwater stream functions, economics, restoration, performance, policy, active management, and disturbance ecology, just to name a few.

The remainder of the article is organized as follows. Section 2 discusses the methodology for the literature review.

\footnotetext{
${ }^{1}$ A copy of the entire database may be found at http://riparianliteratur ereview.blogspot.com/
} 
Table 1. A List of the General Issues

\begin{tabular}{|c|c|}
\hline General Issue & Definition \\
\hline Agriculture & $\begin{array}{l}\text {-For the purpose of this paper, agriculture is used as a means of either an area to protect, create policy for, } \\
\text { study area, or as a non-point source of pollution. }\end{array}$ \\
\hline Buffer Composition & -This is the biological or physical composition of a buffer zone, usually including trees, shrubs, and grass. \\
\hline Buffer Widths & -This is the actual width of the buffer, which can be constant or variable. \\
\hline Ecology & $\begin{array}{l}\text {-For the purpose of this paper, ecology is used as the study of ecosystems, ecology, biology, chemistry, or } \\
\text { restoration. }\end{array}$ \\
\hline Economy & -For the purpose of this paper, an economic focus is used, such as Cost/Benefit analysis of buffers. \\
\hline Effectiveness & $\begin{array}{l}\text {-This is the measurement of whether or not a buffer works with respect to such functions as pollutant } \\
\text { removal, habitat protection. It answers the basic yes or no question, was it effective? }\end{array}$ \\
\hline Efficiency & $\begin{array}{l}\text {-This is the measurement of how well a buffer works with respect to such functions as pollutant removal, } \\
\text { habitat protection. It answers the question, how effective was this buffer and by how much? Authors such } \\
\text { as Ice (2005) and Zorbist et al. (2005) refer to this as optimization. }\end{array}$ \\
\hline Forestry & $\begin{array}{l}\text {-For the purpose of this paper, forestry is used with articles that referred to such terms as logging, stream } \\
\text { debris, or forested buffer strips. }\end{array}$ \\
\hline $\begin{array}{l}\text { Geospatial Information } \\
\text { Technology }\end{array}$ & -This is spatial technology; examples are GIS, Information Technology, Modeling, and Remote Sensing. \\
\hline Government & $\begin{array}{l}\text {-The focus is from a public agency that conducts or commissions a buffer study or that issues buffer } \\
\text { regulations. }\end{array}$ \\
\hline Habitat & -The term habitat, species or wildlife within a buffer are used. \\
\hline Management & $\begin{array}{l}\text {-This describes the management of buffers. This can be active management, stream management, ecosystem } \\
\text { management, forest management or habitat management for example. }\end{array}$ \\
\hline Pollution Filtration & -This is nutrient, pollutant or chemical filtering function or process of buffers. \\
\hline Performance & -This is an optimization, effectiveness and efficiency of buffers. \\
\hline Policy & -Buffers are used in a regulatory manner or within a policy. \\
\hline Protection & $\begin{array}{l}\text {-This is the protection of some function of the buffer, water quality, habitat and species protection is an } \\
\text { example. }\end{array}$ \\
\hline Water Quality & -This refers to quality of water. \\
\hline Zone Types & -Generally describes buffer design or creation of buffer types, filter strips or areas of a riparian nature. \\
\hline
\end{tabular}

Section 3 is a thematic categorization of the literature. Section 4 is a chronicle of buffer studies literature spanning the past three decades. Section 5 is an examination of the convergence of the literature. Section 6 draws conclusions.

\section{Methodology}

This literature review consists of three sets of activities literature survey, analysis, and synthesis.

\subsection{Literature Survey}

To gather literature pertaining to riparian buffer studies, the survey began with online electronic resources - "Academic Search Elite" and "Web of Science". The keywords "riparian" or "riparian buffering" were utilized. The search continued with the same keyword on Google, resulting in several more articles. The references in these articles were used to gather more literature for the survey. Additional readings were included in the search, recommended by experts dealing with riparian buffers. In conjunction with the expert suggested citations, expert opinions were also solicited. Literatures referen- ced in these publications were further retrieved and duplicate articles were removed from the collection. As a result, over 500 articles were obtained and utilized. Once collected, all the publications were documented in a Microsoft Access database with information about the citation, publication date, and a brief summary, preparing the database for this massive literature review analysis. It should be noted that more articles in specialized areas can be found through a keyword search with such terms as "streamside management," "filter strips," and "active management".

\subsection{Literature Analysis and Synthesis}

The review activities, including analysis and synthesis, took place at three levels. Firstly, a thematic analysis grouped publications into three broad thematic categories based upon general issues raised in the literature and a literature review by thematic category. Secondly, a chronicle explicated the evolution of the literature from the 1980's to the 2000's. Thirdly, a synthesis of the literature demonstrated a convergent trend toward a holistic approach in riparian buffer studies. The results of these activities are reported in the subsequent 
sections.

\section{A Thematic Categorization of Riparian Buffer Studies Literature}

In the literature survey, 18 general issues were first identified as common key issues in the publications of riparian buffer studies (see Tables 1). Based upon these general issues, the publications surveyed were then aggregated into three broad thematic categories that are related to the functions, performance, and policies of riparian buffers, respectively (See Table 2 and Figure 1).

Table 2. The Distribution of the General Issues among the Three Categories

\begin{tabular}{lll}
\hline General Issue & $\%$ Frequency & Category \\
\hline Pollution Filtration & $61 \%$ & Performance \\
Agriculture & $37 \%$ & Function \\
Water Quality & $35 \%$ & Function \\
Ecology & $31 \%$ & Function \\
Forestry & $29 \%$ & Function \\
Management & $29 \%$ & Policy \\
Protection & $28 \%$ & Function \\
Geospatial Information & $27 \%$ & Performance \\
Technology & & \\
Buffer Composition & $25 \%$ & Performance \\
Buffer Widths & $23 \%$ & Performance \\
Effectiveness & $23 \%$ & Performance \\
Performance & $20 \%$ & Performance \\
Habitat & $19 \%$ & Function \\
Policy & $16 \%$ & Policy \\
Economy & $13 \%$ & Function \\
Zone Types & $8 \%$ & Policy \\
Efficiency & $7 \%$ & Performance \\
Government & $5 \%$ & Policy \\
\hline
\end{tabular}

\subsection{Buffer Function}

Publications in the Buffer Function category are concerned with (1) the roles that riparian buffers play in water quality protection, soil erosion control, or species preservation; and (2) their capabilities to play these various roles. Several examples exist. Clausen et al. (2000) explored agriculture related issues - a cornfield was reseeded with grass resulting in a decrease in pollution entering the watersystem. Qiu and Prato (1998) researched the economy of riparian buffers using cost/benefit analysis and land use study. Ecology was a factor addressed in Barfield et al. (1998). Their focus was placed on water quality in natural riparian buffer areas, and buffer effectiveness or optimization with different land uses. Hibbs and Bower (2001) described the usefulness of riparian buffer studies related to forestry, explores tree regeneration factors within the riparian buffer. Hanowski et al. (2003) observed birds' response to certain logging practices within the birds' habitats - riparian forest buffers. Spruill's (2004) measured how well riparian buffers filter nitrates, providing an example of the general issues protection and water quality of riparian buffer literature.

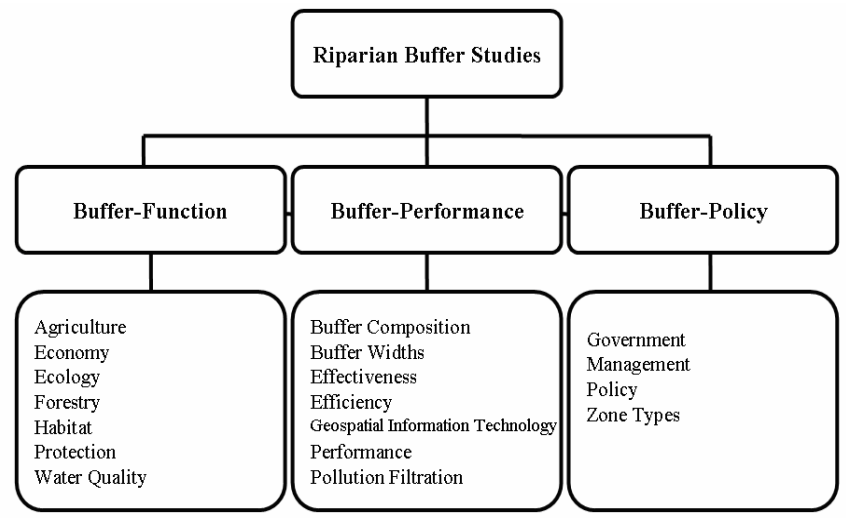

Figure 1. Aggregation of general riparian buffer study issues across three thematic categories.

\subsection{Buffer Policy}

Literatures in the Buffer Policy category focus on regulations, plans or policies for the establishment and maintenance of riparian buffers. Government (Barfield et al., 1998), management (Ice, 1995), policy (Jorgense et al., 2000), and zone types (Blackwell et al., 1999) are general issues in this category. For instance, Inamdar and Dillaha (2000) studied buffer width requirements. Castelle et al. (1999) examined best management practices (BMP) for water quality, tax incentives, and buffer width functions. Zimmerman et al. (2003) investtigated logging along with agricultural policies.

\subsection{Buffer Performance}

Publications in the Buffer Performance category scrutinize the measurement of effectiveness and efficiency of riparian buffers and/or examine tools for the studies of buffer effectiveness and efficiency. There are many examples in the literature survey. For instance, in a review of buffer width requirements, Castelle et al. (1999) analyzed a range of buffer widths for their effectiveness of removing nutrients before runnoff entered the water table. Lee et al. (2000) performed simulated rainfall analysis using land use data, emphasizing the importance of varying widths and buffer composition. Hjelmfelt and Wang (1997) investigated buffer composition and explained the impact vegetation has on water quality. The general issue of buffer effectiveness is exemplified in Bouldin et al. (2004). They performed a comparative assessment of a ditch system's capability of pollution reduction in wastewater with that of the riparian buffers. Zhang et al. (2000) explored the efficiency and effectiveness of buffers in pollution control management. Buffers' efficiency and effectiveness are clearly related to their performance. For example, Clausen et al. (1993) studied the effectiveness and efficiency of rehabilitating riparian buffers once the buffers are removed or damaged. In this study, the efficiency and effectiveness of the ripa- 
rian buffer were used as the measurement of buffer performance. Pollution filtration is a primary topic for several studies. Jacobs and Gilliam (1985) reported alternate facets of pollution reduction. Kuusements et al. (2001) measured the nutrients in water. Shannon et al. (2000) and Spruill (2000) evaluated effectiveness of the buffers to reduce nitrate loads to streams.

This period of time saw a surge in the use of geospatial information technology in riparian buffer studies. For instance, Xiang (1996) used geographic information systems (GIS) modeling in land use planning to assess and create variable buffers - buffer zones of non-constant width. Baker et al. (2001a) and Von Waldow et al. (2002) used landuse and terrain data in GIS to assess nutrient transport. Weng et al. (2003) utilized hydrologic modeling to assess water quality. Lunetta et al. (2003) used geospatial information technology and remote sensing imagery in classifying riparian buffers.

\section{A Chronicle of Riparian Buffer Studies Literature}

The time series analysis in our research revealed the following evolutionary pattern. With a rather modest and less focused literature during the period of 1950's through 1970's (for example, Gleason, 1953; Berntsen and Rothacher, 1959; Fredriksen, 1970 and 1972; Moring and Lantz, 1975; Harr, 1976; Swanson and Lienkaemper, 1978; and Maser et. al., 1978), the riparian buffer studies literature began to emerge with a greater frequency in the 1980's. It grew in both depth and breadth throughout the 1990's, and continues to increase in this manner to the present date. There is a set of commonalities widely shared, but each decade is featured by unique characteristics, emerging themes and trends.

\subsection{The 1980's: Ecosystem, Design, and Filtration}

The riparian buffer studies during the 1980's covered all three thematic areas of function, performance, and policy, with focuses on such issues as design, function, and resilience of riparian ecosystems, habitat reconstruction, farm subsidies, and regulations.

\subsubsection{Buffer function studies in the 1980's}

There was a rise in awareness of the importance of riparian buffers in the 1980's. Vannote et al. (1980) described the relationship of the design, function, and resilience of riparian ecosystems, supporting the "River Continuum Concept" as a major framework. Swanson et al. (1982) defined the riparian zone as "the interface between aquatic and terrestrial environments in coniferous forests which forms a narrow riparian zone." They discussed the design, constituents, and functions of riparian buffers at the ecosystem level. This riparian zone research ties together scientific disciplines and ecosystem components. Rapport et al. (1985) found the commonality between land and water riparian systems when they are under stress and/or disruption, such as forest harvesting, habitat restructure, pollution, exotic species introduction, and/or in the event of a natural disaster.

\subsubsection{Buffer policy studies in the 1980's}

Policy changes were a topic for some of the 1980's literature. Advocating the idea of a worldwide stream management approach, Petersen et al. (1987) stressed the importance of riparian buffers to stream management, and emphasized the interlink of water systems on the Earth. Sedell and Swanson (1982), based upon the benefits of large woody debris for species and habitat, highlighted the significance of forest vegetation to aquatic habitat in riparian ecosystems. Bisson and Sedell (1984) reported a study of certain fish species after forest legislation mandated debris removal, immediately following logging. They found that the types of species and age composition were different than prior to timber harvesting and that this related to habitat change. Bilby (1984) found that removal of large woody debris from streams can seriously change stream channels and affect habitat. He suggested a revised guide to the practice. Maser and Trappe (1984), through a synthesis of data on trees that had fallen in unmanaged old-growth forests, illustrated the ramifications of the practice of large woody debris removal. Bisson et al. (1987) discussed the functions and management of large woody debris in streams in relation to habitat and sediment control as well as water quality issues. Heimlich (1986) measured the marginal cost of highly erodible farmland. He described the policy of agricultural land that was ranked as highly erodible, and suggested that the provision of subsidies under certain farm programs not be paid to those whose crops were raised on land predominate to erosion.

\subsubsection{Buffer performance studies in the 1980's}

Cooper et al. (1987) and Jacobs and Gilliam (1985) investigated riparian buffer's capability to filter pollutants. Phillips (1989a,b,c) studied the filtration performance. Sedell et al. (1989) explored the complexities associated with carbon processing and fish habitat. The diverse interactions along waterways, both spatial and temporal in manner, were discussed as the interaction of the waterway with its forest lined banks and floodplain as part of this critical process. Bradshaw (1983) discussed habitat reconstruction and restocking wildlife and plant species to enhance the performance of riparian buffers.

Osterkamp and Hupp (1984) found that distribution of vegetation species is a controlled process of frequency and intensity of stream flow, and that the plant locations may aid in flood predictions. Harr (1981) examined hydro-meteorological data, finding that erosion at headwater areas pertained to snowmelt during rainfall causing downstream flooding. Campbell and Sidle (1984) calculated predictions for peak streamflows for culvert and road design. Adams et al. (1986) estimated peak streamflow. These issues dealt with avoiding economic and environmental costs associated with large storms and bridge or culvert design failure over streams.

\subsection{The 1990's: Technology, Modeling, and Land Use Planning}

The 1990's saw an expansion in riparian buffer studies along three dimensions of technology, modeling and land use 
planning. The foci spread among a wide range of topics, including buffer policy, management, regulations, standards, economics, buffer performance, geospatial information technology, buffer width and composition. The advancement in science and technology elevated the level of sophistication in riparian buffer studies. Geospatial information technology in studying riparian buffers began an intense exploration, attesting to the true functionality of this tool for riparian buffer studies.

\subsubsection{Buffer function studies in the 1990's}

Water quality protection remained a major function of the riparian buffers. Karr (1991) called for "ecologically sound tools" with a broad base of input from many disciplines to protect water quality. Carpenter et al. (1998), Clausen et al. (1993), Cooper (1993), and Nikolaidis et al. (1993) all focused on water quality by modeling the behavior of non-point source pollutants (NPSP) from agricultural sources within a riparian buffer. Hanson et al. (1994) examined Nitrogen and Carbon contents within riparian buffers. Pinay et al. (1993) explained the pattern of denitrification, estimating the magnitude of buffering capacities. Large et al. (1993) looked at reconstruction of floodplains for water quality protection. Mitsch et al. (1995) examined freshwater riparian marshes as a retention area to extract pollutants from runoff. Blackwell et al. (1999) discussed the use of conventional and alternative locations for riparian buffer zones to remove nitrates from agricultural runoff.

Also reported were other buffer functions that are related to ecosystem components, including riparian habitat and wildlife (for example, Carey and Johnson, 1995), vegetation changes, and stream channel changes. Smith et al. (1991) discussed diversion of streams around hydro-electric plants and its impacts on plant species appearance and growth. Sharitz et al. (1992) recommended that the maintenance of ecological values be part of the management of natural resource and commercial forestry. Hornbeck and Swank (1992) discussed competition between different land uses for riparian sites. They suggested strategies for demonstration of the non-compatible landuses for the ecosystem. Stromberg et al. (1993) revealed the threates that groundwater pumping imposed on species and their habitats. Stromberg et al. (1996) assessed the impacts of groundwater depletion on riparian ecosystems. Decampls (1993) and Naiman et al. (1993) examined biodiversity within riparian buffers. Bell et al. (1997) presented a methodology for review of a large landscape and restoration of ecosystems. Welsh and Ollivier (1998) examined the use of stream amphibians as stress indicators for ecosystems. A USDA report (1993) confirmed that the role of the riparian buffers was important for wildlife habitat. Kerans and Karr (1994) utilized the invertebrate data from the Tennessee Valley Authority (TVA) water systems to assess the condition of riparian habitat and the wildlife within. Debinski and Brussard (1994) used riparian buffer areas to establish techniques for studying species assemblages and their relationships to habitat.

Berg (1995) wrote of the restoration of riparian forests for habitat. Studies by Addy (1999), Darveau et al. (1998), May and Homer (2002), and Weston (1995) examined issues that pertain to riparian buffer performance, land use patterns in and/or around the riparian buffers, biota and animal species protections within buffer habitats. Stevens et al. (1995) studied marshland habitat and the species within. Sala et al. (1996) examined the role of certain types of vegetation within a wetland. They looked for plants with the best water intake and pollution filtration. Walsh and Harris (1996) monitored the habitat preferences of bats within riparian buffers. Darveau et al. (1997) performed a study of the risk of predations amongst bird's nests in riparian forests. Michener et al. (1997) examined storm impacts on coastal wetlands. Darveau et al. (1998) monitored snowshoe hares on their riparian forest habitats. May (1998) studied salmonid habitat in urban streams and Knapp et al. (1998) used riparian buffers to measure spawning habitat and recruitment of salmonids, while Torgerson et al. (1999) examined salmon distribution and behavior. Skagen et al. (1998) studied migrating land birds in a riparian environment. Dobkin et al. (1998) studied habitat, riparian meadow systems, and grazing by livestocks. Stewart and Samways (1998) sampled dragonflies within a riparian buffer habitat. In order to predict bird species distribution across riparian forests, Saab (1999) built their study on spatial scale using three measurements - microhabitat (plant assembleges), macrohabitat (overall riparian forest composition where these species are found), and landscape (riparian buffer composition and surrounding land use). Ferreras and Macdonald (1999) performed a study that assessed the impacts of American mink mustela on water birds. Hughes and Cass (1997) wrote about the impact of flooding along riparian buffers on vegetation patterns Toner and Keddy (1997) modeled hydrologic changes in riparian buffer habitats. Scott et al. (1997) examined the flood dependencies of plants modified by water management activities. Snodgrass (1997) reported that species richness and habitat diversity were attributed to beaver activities in many riparian areas. Stohlgren et al. (1997) looked at riparian plant diversity. Estades and Temple (1999) monitor bird communities and exotic plants within riparian buffer areas. Stohlgren et al. (1999) performed an analysis to show how grazing and soil quality affect plant life, both exotic and native. Young and Huryn (1999) measured sedimentation and landuse to study the affect of land use on a stream's ecosystem.

Several publications addressed the buffer function issues that are related to human activities. Marion and Cole (1996) investigated the impacts of camping sites on vegetation and soil within recreational areas inside riparian buffers. Christensen et al. (1996) investigated the impact of residential development on woody debris abundance within the riparian zones. Cairns and Heckman (1996) discussed human impacts on riparian buffers, and buffer restorations. Reid et al. (1997) studied the impacts of chemical pest-management and landuse on riparian plants, wildlife, and habitat.

\subsubsection{Buffer policy studies in the 1990's}

A surge in publications surfaced that centers on riparian buffer policy, management, regulations, and standards. Coo- 
per (1993) discussed management practices, and technology with respect to assessment of riparian buffer functions. Keiter (1998) called for an integrated approach, including legislations, to ecosystem management. He demonstrated how laws can promote and hindered movement toward incorporation of management and ownership. Barfield et al. (1998), Hubbard and Lowrance (1994) reported buffer management studies on the forest regulations along streams. Dupoldt (1997) and Ice (1995) examined systematically buffer regulations for erosion control, watershed management, water quality protection, and flood controls. Robinson et al. (1997) discussed riparian buffer regulations with examples for development of state standards. Ice et al. (1998) proposed an innovative approach to riparian buffer practices. After examining both forest regulations and buffer requirements, they suggested modification of BMP policies regarding forest buffers and streams. Deutschman and Leach (1998) and Sheridan et al. (1999) examined a number of riparian buffer issues. These include BMP's for water quality protection, land use control, pollution reduction, erosion control, and economic considerations in and around the riparian buffers.

Some policy-oriented literature contributed to the economic aspect of riparian buffer studies. Qiu and Prato (1998), for example, through a cost/benefit analysis, studied the costeffectiveness of agricultural land assemblage with monetary appraisal of riparian buffers.

\subsubsection{Buffer performance studies in the 1990's}

Publications of this decade predominantly examined the performance of riparian buffers. With an increase in enlightenment of how well the riparian buffers control and reduce NPSP (Addy et al., 1999; Gilliam, 1994; Lowrance et al., 1997; Martin et al., 1999; Nikolaidis et al., 1993), issues of buffer restoration (Clausen et al., 1993; Large et al., 1993) and performance (Blackwell et al., 1999) became eminent.

Geospatial information technology, such as GIS, and advanced modeling were premier literature topics pertaining to buffer performance of this period. As a prime example for the use of GIS in riparian buffer modeling and environmental planning, Xiang (1993a,b; 1996) demonstrated, through real world case studies, how spatial technology and modeling can help advance the riparian buffer studies. Tufford et al. (1998) employed GIS to visualize the relationships among streams, land use and pollution within riparian buffers. Xiang (1998) studied the buffer-induced setback effects on riparian aesthetics with GPS and GIS technology. During this period of time, an emerging area of study was watershed modeling, and exemplified by the development and application of such models as the Groundwater Loading Effects of Agricultural Management Systems (GLEAMS). Parsons et al. (1997), for instance, experimented with the GLEAMS model to simulate overland flow of animal wastewater.

Buffer width and composition in relation to buffer performance received much attention from many authors. Based upon Phillips' (1989a,b,c) soil hydrological model, Xiang (1993a,b) developed a GIS approach to calculating variable riparian buffer widths. Bosch et al. (1994) assessed buffer per- formance in relation to different compositions. Brown et al. (1997) compared the benefits of variable buffer widths versus fixed buffers. Castelle et al. (1999) and a study by Kuusemets and Mander (1999) considered varying riparian buffer composition and widths to be important parameters in buffer modeling and scenario composition. Baillie et al. (1999) utilized variable buffers in a soil erosion study. Keim and Schoenholtz (1999) examined riparian buffers at a watershed level.

\subsection{The 2000's: Best Management Practices and Geospatial Information Technology}

The publications of the 2000's feature such topics as buffer function, water quality; buffer policy, management and economics; and buffer performance, effectiveness, buffer wi$\mathrm{dth}$, modeling, geospatial information technology, and remote sensing imagery.

\subsubsection{Buffer function studies in the 2000's}

At this point, there was a cumulated knowledge base from previous decades. The authors further defined the role of the buffer, stretching the fundamentals of riparian buffer studies, posing new questions and performing novel studies of buffer function. This forging and expansion of the fundamentals of riparian buffer knowledge is vital for growth of all riparian buffer function studies.

For instance, Kreutzweiser et al. (2004) investigated the effects of selective harvesting within a forest. Poole and Berman (2001) and Jackson et al. (2001) studied the temperature adjustment function of riparian buffers. Puckett et al. (2002) and Vidon and Hill (2004) analyzed the run-off from melting glaciers and its impacts on the environment. Wilzbach et al. (2005) studied the interwoven relationship between salmon and the forest, based upon the nitrogen nutrient left behind by the fish.

A topic that has not lost focus from previous decades is that of sedimentation and debris within the riparian system. Ice $(2005 a, b)$ highlighted the importance of riparian buffers as a source of wood and debris for streams. This aids water system processes for species, sediment control and habitat. An impact study by Moore and Wondzell (2005) discussed how massive forest harvesting can be a cause of erosion, allowing increased sediment to enter headwater streams, leading to potential downstream flooding.

Water pollution issues continued to be a subject of buffer function studies during this decade. Shannon et al. (2000) demonstrate the benefits of riparian buffers in cleansing water pollution by examing denitrification rates on both poorly and well-drained riparian soils. Davis and Hitchings (2000), Hantush and Marino (2001), Karr et al. (2001), Spruill (2004), and Vellidis and Lowrance (2004) studied the buffer function of ground water quality protection. Kuusemets et al. (2001) and Wigington et al. (2003) explored the relationship between buffer compositions and buffer's runoff purification efficiency. Wiginton et al. (2003) analyzed the effectiveness of grass buffers, while Kuusements et al. (2001) compared types of vegetation, meadow covered and tree covered land, with buffer 
purification efficiency. Meding et al. (2001) and Vellidis and Lowrance (2004) utilized the riparian buffer's natural filtration process to propose projects for municipal water filtration. Their proposal was to spray irrigation over forested buffers showing the capability of the buffer to protect the municipal water supplies and cleanse reclaimed water. Reungsan et al. (2001) explored removal of microbial organisms and pollutants in differing soil types by spraying over forested buffers, allowing the buffer's capability to process.

\subsubsection{Buffer policy studies in the 2000's}

The previous two decades brought about the creation of policies and management of riparian buffer studies. During the 2000's, studies were focusd on re-evaluating policy and management strategies, as well as establishing BMP's. These included such topics as adaptation of management tools for restoring riparian buffer zones, water quality impacts, and data base development for policy implementation (Jorgense et al., 2000). A prime example is the best forest management practices in the Mid-Atlantic region by the Mid-Atlantic Integrated Assessment Program (MAIA) (Thornton et al., 2000). MAIA's is an organization made up of both government and non-government agencies that provides the Mid-Atlantic region with supports for environmental decision-making processes. These include, but are not limited to, scientific and monitoring tools, products and reports, and provision of reliable data (EPA, 2005). Jorgense et al. (2000) found some aspects of MAIA were in need of revamping, and suggested goals and tools for managing different aspects of riparian buffers ecosystem restoration.

Other policy related studies were reported from a wide range of topic areas. We found several authors discussed riparian management practices (Booth et al., 2002; Scott et al., 2002; Vache et al., 2002). Hancock (2002) demonstrated the importance of buffer performance to land use policies, calling for more effective land use practices and policies for pollution filtration. To improve the efficiency and effectiveness of pollution control management, Zhang et al. (2000) examined factors that contribute to the transport of pollutants from wastewater sites. Nerbonne and Vondracek (2001) studied erosion control along with habitat, pollution and buffer composition in defining the optimal buffer zones, relating to riparian buffer management practices. Scott et al. (2002) discussed the benefits of retaining and managing native natural buffer areas. Ice (2000) wrote of the importance of an active management approach to the achievement of a balance between environmental and economic goals at the watershed level. Horner et al. (2002) discussed Storm Water BMP designs. Booth et al. (2002) studied a BMP case for watershed conservation in the rural areas. Vache et al. (2002) suggested BMP for water quality protection through the scenarios composed with the Soil \& Water Assessment Tool (SWAT).

Part of re-evaluation of policy and management enveloped economic aspect of riparian buffer studies. Ice $(2005 \mathrm{a}, \mathrm{b})$ compared U.S. Pacific Northwestern states forest practice rules looking at the point of diminishing return between the environmental and economic implications involved. Matero
(2004) wrote about the cost-effectiveness of managing riparian buffers. To achieve the dual objective of reducing phosphorus leaching and minimizing cost, he proposed a series of measures, including maintenance of proper drainage, riparian buffer creation, and suggested that multiple factors be taken into account. These include such factors as the affects on water pollution, forest harvesting, a technology review, economic factors, and cost effectiveness. The USDA Cost Share Program attached economic incentives to the maintenance of riparian buffers and the species within (Lowrance et al., 2001). Utilized a hydrologic modeling process, Riparian Ecosystem Management Model (REMM), the program scrutinized quailty of water and nutrient load, pointing out the importance of acceptable variable buffer widths for optimal effectiveness.

\subsubsection{Buffer performance studies in the 2000's}

During this time period, the performance studies embraced a broader range of factors, such as type, width and composition of riparian buffers. Oelbermann and Gordon (2000) studied how buffer restoration can enhance buffer's performance. Zimmerman et al. (2003) studied habitat and erosion control, investigating land use's contribution to loading sediment into waterways and its impacts on the fish communities. Wynn et al. (2004) considered performance issues when examining stream-bank stabilization. Bouldin et al. (2004) researched buffer's effectiveness and/or capability of runoff pollution removal in camparison with those of ditch systems. Dukes et al. (2002) tested riparian buffer widths in water quality studies. Hannon et al. (2002) measured performance of riparian buffers, before and after harvesting, with respect to various species residing within an experimental forest buffer of variable width. Hanowski et al. (2003) studied bird species' response to different harvesting techniques in their habitats.

The measurement of riparian buffer performance can also be used as the evaluation of effectiveness and optimal buffer width. Spruill (2000) measured nitrates on ground water quality, looking for the most effective process. Lowrance et al. (2001) studied riparian buffers to calculate optimal buffer width. Both authors were searching for the optimal buffer effecttiveness by looking at two different processes. This trend continued as a favored topic in conjunction with other topics in publications of this instance of time. Kreutzweiser and Capell (2002) examined whether riparian buffers reduce sediment load delivered from selective harvesting land, and made the suggestion that buffer effectiveness analysis be integral part of ground water management practices. In a water supply master plan review, Choi (2001) assessed the effectiveness of riparian buffers in protecting water supplies. Denny (2001) discussed management of riparian buffers for effectiveness.

There were performance studies that focused on investment; policy and inventory of wetlands. For example, Reeves (2004) examined the policy of tax credits given for forest buffered land, and measured whether it is efficient for the company to use the tax credits. He found that the monetary value of the trees exceeded the value of the total tax credit amounts for logging of certain crops. For future restoration and management of conservation easements along certain 
streams, Thompson (2001) assessed feasibility of performance and effectiveness of a riparian buffer. On a calculation of effectiveness, May and Horner (2002) proposed stream design standards, and called for a minimization of impervious surfaces. Lamb et al. (2003) called for a re-evaluation of buffer management guidelines to incorporate the effectiveness and performance of the riparian buffer policies.

The advancement in geospatial information technology, especially GIS, continued to contribute to buffer performance studies. Montas et al. (2000) used Hydrosub to measure the riparian buffer impacts on water quality. Leland (2000) reported the use of GIS in studies of stream temperature within a riparian zone. Baker et al. (2001a,b) used GIS based models that incorporated multiple factors, such as land use/cover and terrain-based data to prove the buffer's potential for reducing water pollutants. Carver et al. (2004) and Stewart et al. (2001) applied GIS to delineation of riparian buffer boundaries. They also demonstrated how GIS can help determine the best vegetation compositions for buffers.

Spatial modeling made further advancement in the measurement of buffer performance. Clausen et al. (2000) used modeling and simulation of ground conditions in a buffer analysis, measuring several aspects of the riparian buffer zone against one another. Utilizing GIS, Fitzpatrick et al. (2001) was able to determine water quality indicators for stream assessment. Poole and Berman (2001) argued that there is an ecological perspective on stream-temperature impact assessment in the Mechanistic Temperature Models, and demonstrated that geospatial information technology tools can benefit the modeling of these complex processes. Vellidis (inconstant with the reference) and Lowrance (2004) used the Reduction of NPSP Model and Management model (RFBS) to describe the movement of water runoff and nitrate in groundwater toward streams. Simpkins et al. (2002) applied Recirculation Infusion Mash System (RIMS System) to model buffers along shallow groundwater flow systems. Stone et al. (2001) and Cerucci and Conrad (2003) expanded nutrient transport models. They used the Groundwater Loading Effects of Agricultural Management Systems (GLEAMS) and REMM in their riparian buffer studies. These types of studies relayed visualization of the processes within the buffer. Popular hydrologic models SWAT (Vache et al., 2002; Cerucci and Conrad, 2003) and MARTHE (Weng et al., 2003) were used to simulate water flow issues. There were still other ecological risk assessment frameworks that were used to predict NPSP vulnerability. Potter et al. (2004) assessed the risk of water quality and aquatic biodiversity associated with land use variations, and demonstrated how this information can help policy makers and natural resources managers to improve their practice. Djodjic et al. (2002) used GLEAMS as an environmentally focused Decision Support System to facilitate planning practitioners to develop BMP's. A comprehensive index of these and other riparian buffer models can be found in Parsons et al. (2001).

Remote sensing of the landscape emerged as a subject of riparian buffer performance studies during the 2000's. For example, Lunetta et al. (2003) reported a project in which GIS, remote sensing imagery and quantitative assessment models were integrated to support decision-making in and around riparian buffers. The use of imagery has eased the need for some field collection tasks. Klemas (2001) discussed the alternative management scenarios using rasterized land use data derived from satellite imageries. In a scenario analysis, Congalton et al. (2002) used changing parameters in datasets to produce and run riparian buffer simulation studies. Their approach can be readily adapted by analysts in different policy environments. A comprehensive index of riparian buffer models can be found in Parsons et al. (2001).

\section{The Convergence of the Literature}

Although the above thematic categorization serves the purpose of analysis well, a large percentage of the publications (over 80\%) address issues across thematic categories. This convergence of thematic categories in the literature may reflect the realization within the riparian buffer studies community about the interwoven nature of the various aspects of riparian buffer studies. As shown in the Venn Diagram in Figure 2 , the convergence takes place at three levels.

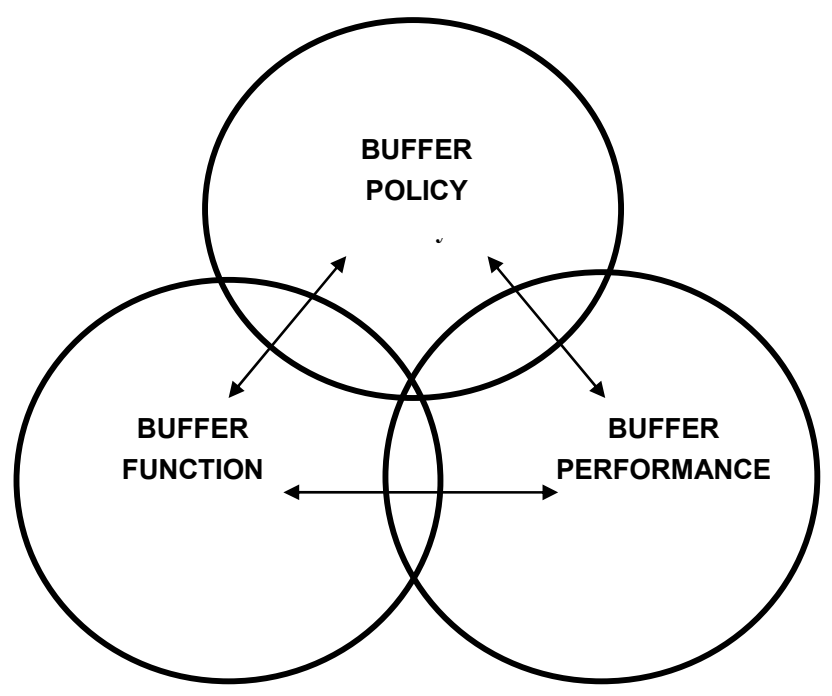

Figure 2. The Interconnectivity between the three thematic categories.

\subsection{The Three Levels of Literature Convergence}

A publication qualifies for placement in first-order convergence when it clearly falls within one of the three thematic categories (that is, buffer function, buffer policy, or buffer performance). Over $10 \%$ of the literature fits within this realm.

Literature may only fall within the Function Category. For instance, Sedell and Swanson (1982) discussed the characteristics of stream ecology, habitat, wildlife, debris and sediment. Vannote et al. (1980) discussed the physical characteristics of a river system. Literature may also only fall within the Policy Category. For example, Brinson and Rheinhardt (1996) measured the function of wetlands. This proposed a standardized approach to analysis may then reinforce this tie 
between wetland policy, resources and ethics. Some literature may only fall within the Performance Category. For instance, Soranno et al. (1996) measured NPSP, utilizing GIS modeling. Goetza et al. (2003) examined the use of IKONOS satellite imagery for resource management. Nagler et al. (2005) created a vegetation index model from Moderate Resolution Imaging Spectrometer (MODIS).

A publication qualifies for placement in second-order convergence when it has a combination of two out of the three categories (that is, buffer function and buffer policy, buffer function and buffer performance, or buffer policy and buffer performance). Over $50 \%$ of literatures fall within this realm. However, there is no clear division between most of the buffer publications - many overlap in thematic category. There are several examples from the literature which illustrate this overlap of thematic categories. Subjects vary.

A number of publications, from our literature survey, have a tendency to be in the category of buffer policy and buffer performance. McGlynn and Seibert (2003) wrote an article on applied computation of effectiveness that encompasses the general issues of policy and performance. Another example is the buffer width and the composition requirements study by Dukes et al. (2002).

Literatures that straddle between the thematic categories of buffer function and buffer performance adhere to several issues. These include, ecological effects from certain land use (Zimmerman et al., 2003 and Boothroyd et al., 2004), water quality protection and economic values of buffers (Qiu and Prato, 2001; Boothroyd et al., 2004), effects of logging (Dignan and Bren, 2003), watershed impacts (Montas et al., 2000), buffer restoration and buffer performance (Clausen et al., 2000), buffer widths and composition (Lee et al., 2000). In addition, Hubbard and Lowrance (1994) performed an impact stream assessment in search of criteria for an optimal approach to water quality protection by riparian forest buffers. The US Geological Survey (USGS) reported on the effectiveness of different riparian buffers in controlling ground-water discharge of nitrate to streams (Spruill, 2004). Bosch et al. (1994) assessed the performance of different field types in water quality protection. Lowrance et al. (1997) observed the herbicide transport under different vegetation covers and in various spatial locations with respect to stream proximity. Wigington et al. (2003) examined the effectiveness of grass buffers in pollutant removal from streams.

Literature covering buffer function and buffer policy varied by topic, geared toward such issues as habitat, species, vegetation, regulation, standards, conservation, and/or rehabilitation. Shirley (2004) discussed the influences of riparian buffers on habitat, diversity, and buffer width. McClain and Cassio (2003) utilized multiple criteria to measure specific vegetation features with focus on the riparian environments. They also answered questions about mechanisms for conservation, while reviewing the values local residents place on the riparian environments. Miltner et al. (2004) called for a larger regulatory framework with supportive rationale. May and Horner (2002) and Nerbonne and Vondracek (2001) designed storm water management standards for conservation and habi- tat preservation. Within this integration order, Large et al. (1993) and Poole and Berman (2001) called for the development of sound management strategies for rehabilitating riparian buffer zones to serve the purposes of conservation and water quality protection.

A publication qualifies for placement in third-order convergence if it has components of all three thematic categories (that is, buffer function, buffer policy, and buffer performance). This will be referred to hereafter as a holistic approach to riparian buffer studies as it strives to reach a balance among economical, environmental, and social goals. A significant portion of the literature, roughly $30 \%$, is within this realm. Simpkins et al. (2002) looked at the use of modeling, while Cerucci and Conrad (2003) used geospatial information technology, to provide decisions for protecting water quality, buffer performance, and optimizing affordable riparian buffers widths. Qiu and Prato (1998) deemed the importance of the cost and benefit analysis in riparian buffer studies. The USDA set standards for BMP's, recommending different buffer widths to protect forests and protect water quality (Sheridan et al., 1999). Ice (2005a) discussed the streamside management zones and forestry programs for several U.S. Pacific Northwestern States. Ice (2005b) systematically addressed several issues, including active management, assessment tools, models, selective harvesting, the use of exclusion zones, zone types and economic aspects of riparian buffers, and the idea of riparian buffer optimization. Similar idea of optimization was discussed in Zorbist et al. (2005). They took a holistic view of various issues surrounding riparian buffers, including legislature, management, buffer composition and widths, ecosystem health, logging, efficient economics and performance, and habitat protection. Jorgense et al. (2000) combined restoration, monitoring, design, composition and assessment of riparian areas. Choi (2001) described the buffer establishment and management in a master plan for water supply source protection. Denny (2001) discussed the building of a wetland inventory system and development of a management policy. Nerbonne and Vondracek (2001) suggested BMP's in riparian buffer zones for habitat and species, erosion, pollution, management, composition and widths. Ice et al. (1998) described state guidelines for modification of forest practice rules, and discussed buffer requirements under a fully integrated approach. This convergence of thematic categories suggests clearly a thrust towards a holistic approach to riparian buffer studies.

\subsection{Distribution of the Literature across the Three Levels}

The distribution of this integration reveals a movement of the literature towards this third-order convergence. The distribution resembles a pentagon (see Figure 3.). Most of the literature currently falls into the second-order convergence, the next largest group falls into the third-order convergence.

\subsection{A Chronicle of the Convergence}

The convergence of thematic categories intensifies from 1980's through the 2000's, suggesting a movement towards a holistic approach to riparian buffer studies. In the 1980's, the 
literature was mainly focused on buffer function or buffer policy. In the 1990's, there was an increasing number of the literature that address buffer function, buffer policy and buffer performance. In the 2000's, there was a slight, although important, shift in the literature towards the research topics and activities that involve issues across all three thematic categories. This convergence of the literature is evident as shown in Figure 4.

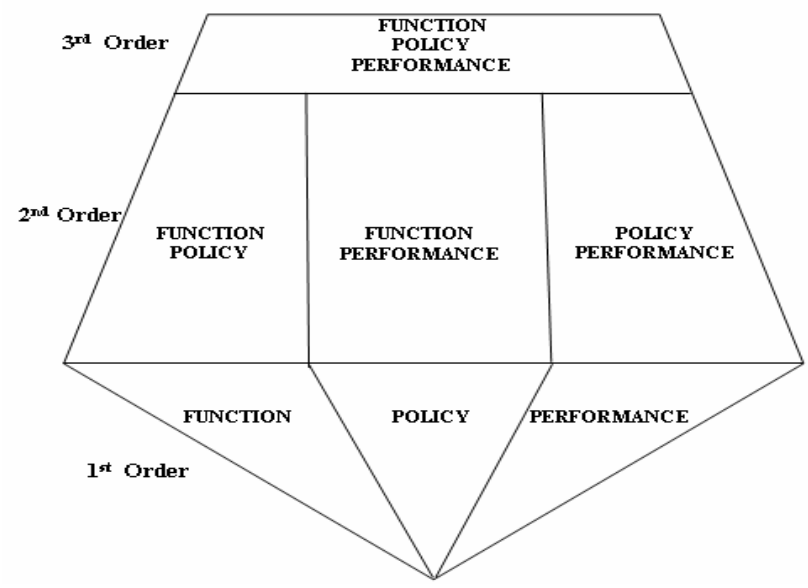

Figure 3. The riparian buffer studies distribution by characteristic.

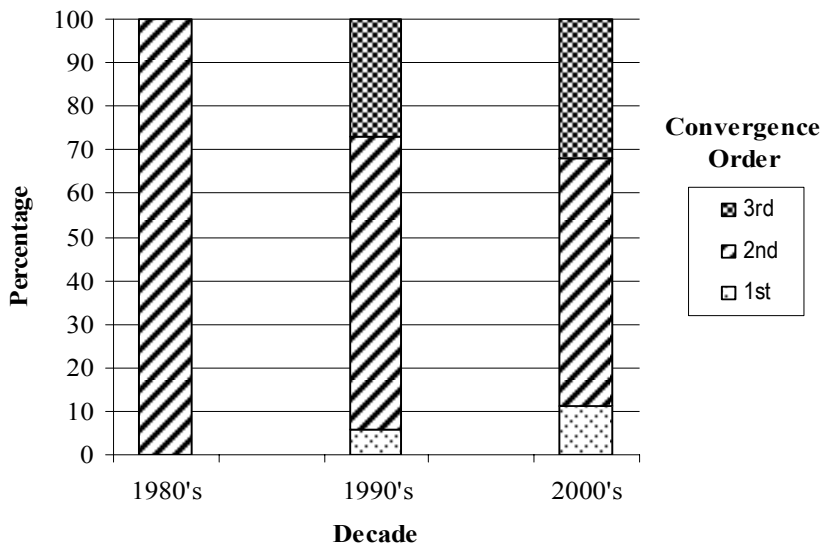

Figure 4. The chronicle of literature by thematic category.

\section{Conclusions}

The two most eminent characteristics of riparian buffer studies that our review of over 500 articles revealed are the sustained advocacy for a holistic approach from authors across a vast range of disciplines, and the successful adaptation of geospatial information technology by the research community. We predict that there will be more publications that cover the emerging topics discussed in the review, and there will be new emerging topics to be reported. We expect future publications on the successful implementation of the holistic approach to riparian buffer studies.
Acknowledgments. The authors express their sincere appreciations to George Ice for his valuable comments and suggestions on the early version of this article.

\section{References}

Adams, P., Campbell, A., Sidle, R., Beschta, R. and Froehlich, H. (1986). Estimating Streamflows on Small Forested Watersheds for Culvert and Bridge Design in Oregon, Forest Research Laboratory, Research Bulletin 55.8, Oregon State University, Corvallis.

Addy, K.L., Gold, A.J., Groffman, P.M. and Jacinthe, P.A. (1999). Ground water nitrate removal in subsoil of forested and mowed riparian buffer zones. J. Environ. Qual., 228(3), 962-970.

Baillie, B.R., Cummins, T.L. and Kimberley, M.O. (1999). Harvesting effects on woody debris and bank disturbance in stream channels. New Zealand J. For. Sci., 29(1), 85-101.

Baker, M.E., Wiley, M.J. and Seelbach, P.W. (2001). GIS-based hydrologic modeling of riparian areas: implications for stream water quality. J. Am. Water Resour. Assoc., 37(6), 1615-1628.

Baker, T., Lockaby, B., Conner, W., Meier, C., Stanturf, J. and Burke, M. (2001). Leaf litter decomposition and nutrient dynamics in four southern forested floodplain communities. Soil Sci. Soc. Am. J., 65, 1334-1347.

Barfield, B.J., Blevins, R.L., Fogle, A.W., Madison, C.E., Inamdar, S., Carey, D.I. and Evangelou, V.P. (1998). Water quality impacts of natural filter strips in karst areas. Trans. ASAE, 41(2), 371-381.

Bell, S., Fonseca, M. and Motten, L. (1997). Linking restoration and landscape ecology. Restorat. Ecol., 5(4), 318-323.

Berg, D. (1995). Riparian silvicultural system design and assessment in the Pacific Northwest Cascade Mountains, USA. Ecol. Appl., $5(1), 87-96$.

Berntsen, C. and Rothacher, J. (1959). A Guide to the H.J. Andrews Experimental Forest, Portland, US Department of Agriculture, Forest Service, Pacific Northwest Forest and Range Experiment Station, 21.

Bilby, R. (1984). Removal of woody debris may affect stream channel stability. J. For, 609-613.

Bisson, P., Bilby, R., Bryant, M., Dolloff, C., Grette, G., House, R., Murphy, M., Koski, K. and Sedell, J. (1987). Large woody debris in forested streams in the Pacific Northwest: past, present, and future, in E.O. Salo and T.W. Cundy (Eds.), Streamside Management: Forestry and Fisheries Interactions, UW Forestry Publication No. 59, Seattle, WA.

Bisson, P. and Sedell, J. (1984). Salmonid populations in streams in clearcut vs. old-growth forests of western Washington, presented in Timber Management/Fish Management Productivity, pp. 121-129.

Blackwell, M.S.A., Hogan, D.V. and Maltby, E. (1999). Use of conventionally and alternatively located buffer zones for the removal of nitrate from diffuse agricultural run-off. Water Sci. Technol., 39(12), 157-164.

Booth, D.B., Hartley, D. and Jackson, R. (2002). Forest cover, impervious-surface area, and the mitigation of stormwater impacts. $J$. Am. Water Resour. Assoc., 38(3), 835-845.

Boothroyd, I.K.G., Quinn, J.M., Langer, E.R., Costley, K.J. and Steward, G. (2004). Riparian buffers mitigate effects of pine plantation logging on New Zealand streams: Riparain vegetation structure, stream geomorphology and periphyton. For. Ecol. Manage., 194(1), 199-213.

Bosch, D.D., Hubbard, R.K., West, L.T. and Lowrance, R.R. (1994). Subsurface flow patterns in a riparian buffer system. Trans. ASAE, 37(6), 1783-1790.

Bouldin, J.L., Farris, J.L., Moore, M.T. and Cooper, C.M. (2004). Vegetative and structural characteristics of agricultural drainages in the Mississippi delta landscapes. Environ. Pollut., 132 (3), 403-411. 
Boulet, M., Darveau, M. and Belanger, L. (2003). Nest predation and breeding activity of songbirds in riparian and nonriparian black spruce strips of central Quebec. Can. J. For. Res., 33(5), 922.

Bradshaw, A. (1983). The reconstruction of ecosystems. J. Appl. Ecol., 20, 1-17.

Brinson, M. and Rheinhardt, M. (1996). The role of reference wetlands in functional assessment and mitigation. Ecol. Appl., 6(1), 69-76.

Brown, E.W., Jones, J.E. and Clary, J.K. (1997). Criteria for establishing variable-width stream buffers in the Rocky Mountains, in Proc. Congress of the International Association of Hydraulic Research, Environmental and Coastal Hydraulics: Protecting the Aquatic Habitat, pp. 462-467.

Hydraulics: Brown, E.W., Jones, J.E. and Clary, J.K. (1997). Criteria for variable-width mountain stream buffers, in Proc. of the Annual Water Resources Planning and Management Conference, Aesthetics in the Constructed Environment, pp. 174-179.

Cairns, J. and Heckman, J. (1996). Restoration ecology: the state of an emerging field. Annu. Rev. Energy Environ., 21, 167-189.

Campbell, A. and Sidle, R. (1984). Prediction of peak flows on small watersheds in Oregon for use in culvert design. Water Resour Bull., 20(1), 9-14.

Carey, A. and Johnson, M. (1995). Small mammals in managed, naturally young, and old-growth forests. Ecol. Appl., 5(2), 336-352.

Carpenter, S., Caraco, N., Correll, D., Howarth, R., Sharpley, A. and Smith, V. (1998). Nonpoint pollution of surface waters with Phosphorus and Nitrogen. Ecol. Appl., 8(3), 559-568.

Carver, A.D., Danskin, S.D., Zaczek, J.J., Mangun, J.C. and Williard, K.W.J (2004). A GIS methodology for generating riparian tree planting recommendations. Northern J. Appl. For, 21(2), 100106.

Castelle, A.J., Johnson, A.W. and Conolly, C. (1999). Wetland and stream buffer size requirements. J. Environ. Qual., I-781, 76.

Cerucci, M. and Conrad, J.M. (2003). The use of binary optimization and hydrologic models to form riparian buffers. J. Am. Water Resour. Assoc., 39(5), 1167-1180.

Choi, J.Y. (2001). Establishement and management of riparian buffer zones in Han River basin, Korea. Prog. Water Resour., 109-115.

Christensen, D., Herwig, B., Schindler, D. and Carpenter, S. (1996). Impacts of lakeshore residential development on coarse woody debris in north temperate lakes. Ecol. Appl., 6(4), 1143-1149.

Clausen, J.C., Guillard, K., Sigmund, C.M. and Dors, K.M. (2000). Water quality changes from riparian buffer restoration in Connecticut. J. Environ. Qual., 29(6), 1751-1761.

Clausen, J.C., Wayland, K.G., Saldi, K.A. and Guillard, K. (1993). Movement of nitrogen through an agricultural riparian zone: field studies. Water Sci. Technol., 28(3-5), 605-612.

Congalton, R.G., Birch, K., Jones, R. and Schriever, J. (2002). Evaluating remotely sensed techniques for mapping riparian vegetation. Comput. Electron. Agric., 37(1-3), 113-126.

Cooper, C.M. (1993). Biological effects of agriculturally derived surface water pollutants on aquatic systems. J. Environ. Qual., 22 (3), 402-408.

Cooper, J.R., Gilliam, J.W., Daniels, R.B. and Robarge, W.P. (1987). Riparian areas as filters for agricultural sediment. Soil Sci. Soc. Am. J., 51(2), 416-420.

Correll, D. (2005). Principles of planning and establishment of buffer zones. Ecol. Eng., 24, 433-439.

Darveau, M., Belanger, L., Huot, J., Melancon, E. and DeBellefeuille, S. (1997). Forestry practices and the pisk of bird nest predation in a boreal coniferous forest. Ecol. Appl., 7(2), 572-580.

Darveau, M., Huot, J. and Belanger, L. (1998). Riparian forest strips as habitat for snowshoe hare in a boreal balsam fir forest. Can. $J$. For. Res., 28(10), 1494-1500.

Davis, P. and Hitchings, B. (2000). Protecting stored water with riparian buffers. Public Works, 131(3), 30.
Debinski, D. and Brussard, P. (1994). Using biodiversity data to assess species-habitat relationships in Glacier National Park, Montana. Ecol. Appl., 4(4), 833-843.

Decampls, H. (1993). River margins and environmental change. Ecol. Appl., 3(3), 441-445.

Denny, P. (2001). Research, capacity-building and empowerment for sustainable management of African wetland ecosystems. Hydrobiologia, 458, 21-31.

Deutschman, M.R. and Leach, M. (1998). Water quality of the clearwater river-effect of nonpoint sources and a strategy for improvement, in Proc. of ASCE Wetlands Engineering River Restoration Conference, pp. 6.

Dignan, P. and Bren, L. (2003). A study of the effect of logging on the understory light environment in riparian buffer strips in a southeast Australian forest. For. Ecol. Manage., 172(2-3), 161172.

Djodjic, F., Montas, H., Shirmohammadi, A., Bergstrom, L. and Ulen, B. (2002). A decision support system for phosphorus management at a watershed scale. J. Environ. Qual., 31(3), 937-945.

Dobkin, D., Rich, A. and Pyle, W. (1998). Habitat and avifaunal recovery from livestock grazing in a riparian meadow system of the northwestern Great Basin. Conserv. Biol., 12(1), 209-221.

Dukes, M.D., Evans, R.O., Gilliam, J.W. and Kunickis, S.H. (2002). Effect of riparian buffer width and vegetation type on shallow groundwater quality in the middle coastal plain of North Carolina. Trans. ASAE, 45(2), 327-336.

Dupoldt, C.Jr. (1997). Localized storm water management: beyond the borders. Pollut. Eng., 29(3), 58-59.

EPA (2005). Mid-Atlantic Integrated Assessment Goal Statement (MAIA). http://www.epa.gov/maia/.

Estades, C. and Temple, S. (1999). Deciduous-forest bird commnities in a fragmented landscape dominated by exotic pine plantations. Ecol. Appl., 9(2), 573-585.

Ferreras, P. and Macdonald, D. (1999). The impact of American mink mustela vison on water birds in the upper Thames. J. Appl. Ecol., 36(5), 701-708.

Fitzpatrick, F.A., Scudder, B.C., Lenz, B.N. and Sullivan, D.J. (2001) Effects of multi-scale environmental characteristics on agricultural stream biota in eastern Wisconsin. J. Am. Water Resour. Assoc., 37(6), 1489-1507.

Fredriksen, R. (1970). Erosion and Sedimentation Following Road Construction and Timber Harvest on Unstable Soils in Three Small Western Oregon Watersheds, Paper PNW-104, US Department of Agriculture Forest Service Research US Department of Agriculture, Forest Service, Pacific Northwest Forest and Range Experiment Station, Portland.

Fredriksen, R. (1972). Nutrient budget of a douglas-fir forest on an experimental watershed in western Oregon, in Proc. of Research on Coniferous Forest Ecosystems-A Symposium, Bellingham, Washington, pp. 115-131.

Gilliam, J.W. (1994). Riparian wetlands and water quality. J. Environ. Qual., 23(5), 896-900.

Gleason, C. (1953). Indicators of erosion on watershed land in California. Trans., Am. Geophys. Union, 34(3), 419-425.

Goetza, S., Wright, R., Smith, A., Zinecker, E. and Schaubb, E. (2003). IKONOS imagery for resource management: Tree cover, impervious surfaces, and riparian buffer analyses in the mid-Atlantic region. Remote Sens. Environ., 88(1/2), 195-208.

Hairston-Strang, A. and Adams, P. (2000). Potential large wood debris sources in riparian buffers after harvesting in Oregon, USA. For. Ecol. Manage., 112, 67-77.

Hancock, P.J. (2002). Human impacts on the stream-groundwater exchange zone. Environ. Manage., 29(6), 763-781.

Hannon, S.J, Paszkowski, C.A., Boutin, S., Degroot, J., Macdonald, S.E., Wheatley, M. and Eaton, B.R. (2002). Abundance and species composition of amphibians, small mammals, and songbirds 
in riparian forest buffer strips of varying widths in the boreal mixed wood of Alberta. Can. J. For. Res., 32(10), 1784.

Hanowski, J., Danz, N., Lind, J. and Niemi, G. (2003). Breeding bird response to riparian forest harvest and harvest equipment. For. Ecol. Manage., 174(1-3), 315-328.

Hanson, G., Groffman, P. and Gold, A. (1994). Symptoms of nitrogen saturation in a ripararian wetland. Ecol. Appl., 4(4), 750-756.

Hantush, M.M. and Marino, M.A. (2001). Analytical modeling of the influence of denitrifying sediments on nitrate transport in aquifers with sloping beds. Water Resour. Res., 37(12), 3177-3192.

Harr, R. (1976). Hydrology of small forest streams in Western Oregon, USDA Forest Service General Technical Report, PNW-55.

Harr, R. (1981). Some characteristics and consequences of snowmelt during rainfall in western Oregon. J. Hydrol., 53, 277-304.

Heimlich, R. (1986). Agricultural programs and cropland conversion, 1975-81. Land Econ., 62(5), 174-181.

Hibbs, D.E. and Bower, A.L. (2001). Riparian forests in the Oregon coast range. For. Ecol. Manage., 154(1-2), 201-213.

Hjelmfelt, A. and Wang, M. (1997). Using modeling to investigate impacts of grass waterway on water quality, in Proc. Congress of The International Association of Hydraulic Research, Iahr, Environmental and Coastal Hydraulics, Protecting The Aquatic Habitat, B(2), 1420.

Hornbeck, J. and Swank, W. (1992). Watershed ecosystem analysis as a basis for multiple-use management of eastern forests. Ecol. Appl., 2(3), 238-247.

Horner, R., May, C., Livingston, E., Blaha, D., Scoggins, M., Tims, J. and Maxted, J. (2002). Structural and non-structuealBMPs for protecting streams, Linking Stormwater BMP Designs and Performance to Receiving Water Impact Mitigation, pp. 60-77.

Hubbard, R. and Lowrance, R. (1994). Riparian forest buffer system research at the coastal plain experiment station, Tifton, Ga. Water, Air Soil Pollut., 77(3-4), 409-432.

Hughes, J. and Cass, W. (1997). Pattern and process of a floodplain forest, Vermont, USA: Predicted response of vegetation to perturbation. J. Appl. Ecol., 34(3), 594-612.

Ice, G. (1995). Managing riparian zones and watersheds with state forest practice programs, in Watershed Mangement: Planning for the $21^{\text {st }}$ Century, pp. 290-299

Ice, G. (2005). Forest riparian protection in the Pacific Northwest. Western For., 50(2), 8-10

Ice, G. (2005). Riparian buffers: Optimizing environmental beneits, presented at the Science and Policy of Wildlife and Salmon, Western Forestry and Conservation Association, World Forestry Center, Portland, OR.

Ice, G. (2000). The use of active watershed management to achieve or accelerate the accomplishment of watershed goals. Watershed Manage., ASCE Proc., 36(2).

Ice, G., Schmedding, D. and Shepard, J. (1998). State restrictions and initiatives to restrict the use of silvicultural chemicals: What we know and need to know, in Proc. of the NCASI Northeast Regional Meeting, Research Triangle Park, National Council for Air and Stream Improvement, Inc. pp. 303-317.

Inamdar, S. and Dillaha, T. (2000). Relationships between drainage area, slope length, and slope gradient for riparian slopes $\mathrm{n}$ Virginia. Trans. ASAE, 43(4), 861-866.

Jackson, C.R., Sturm, C.A. and Ward, J.M. (2001). Timber harvest impacts on small headwater stream channels in the coast ranges of Washington. J. Am. Water Resour. Assoc., 37(6), 1533-1549.

Jacobs, T.C. and Gilliam, J.W. (1985). Riparian losses of nitrate from agricultural drainage waters. J. Environ. Qual., 14(4), 472-478

Jorgense, E.E., Cnfield, T.J. and Kutz, F.W. (2000). Restored riparian buffers as tools for ecosystem restoration in the MAIA: Processes, endpoints, and measures of success for water, soil, flora, and fauna. Environ. Monit. Assess., 63(1),199-210.
Karr, J. (1991). Biological Integrity: A long-neglected aspect of water resource management. Ecol. Appl., 1(1), 66-84.

Karr, J.D., Showers, W.J., Gilliam, J.W. and Andres, A.S. (2001). Tracing nitrate transport and environmental impact from intensive swine farming using delta nitrogen-15. J. Environ. Qual., 30(4), 1163-1175.

Keim, R.F., and Schoenholtz, S.H. (1999). Functions and effectiveness of silvicultural streamside management zones in loessial bluff forests. For. Ecol. Manage., 118(1-3), 197-209.

Keiter, R. (1998). Ecosystems and the law: Toward an integrated approach. Ecol. Appl., 8(2), 332-341.

Kerans, B. and Karr, J. (1994). A benthic index of biotic integrity (B-IBI) for rivers of the Tennessee valley. Ecol. Appl., 4(4), 768-785.

Klemas, V.V. (2001). Remote sensing of landscape-level coastal environmental indicators. Environ. Manage., 27(1), 47-57.

Knapp, R., Vredenburg, V. and Matthews, K. (1998). Effects of stream channel morphology on golden trout spawning habitat and recruitment. Ecol. Appl., 8(4), 1104-1117.

Kreutzweiser, D.P. and Capell, S.S. (2002). Erratum: fine sediment deposition in streams after selective forest harvesting without riparian buffers (Can. J. For. Res., 31, (2134-3142)). Can. J. For. Res., 32(6), 1108.

Kreutzweiser, D.P., Capell, S.S. and Beall, F.D. (2004). Effects of selective forest harvesting on organic matter inputs and accumulation in headwater streams. Northern J. Appl. For, 21(1), 1930 .

Kuusemets, V., Mander, U., Lohmus, K. and Ivask, M. (2001). Nitrogen and phosphorus variation in shallow groundwater and assimilation in plants in complex riparian buffer zones. Water Sci. Technol., 44(11-12), 615-622.

Kuusemets, V. and Mander, U. (1999). Ecotechnological measures to control nutrient losses from catchments. Water Sci. Technol., 40 (10), 195-202

Lamb, E.G., Mallik, A.U. and Mackereth, R.W. (2003). The early impact of adjacent clearcutting and forest fire on riparian zone vegetation in northwestern Ontario. For. Ecol. Manage., 177(1-3), 529-538.

Large, A.R.G., Petts, G.E., Wilby, R.L. and Greenwood, M.T. (1993). Restoration of floodplains: A UK perspective. Eur. Water Pollut. Control, 3(5), 44-53.

Lee, K.H., Isenhart, T.M., Schultz, R.C. and Mickelson, S.K. (2000). Multispecies riparian buffers trap sediment and nutrients during rainfall simulations. J. Environ. Qual., 29(4), 1200-1205.

Leland, D. (2000). Development of the technical basis for a temperature TMDL for the Navarro river watershed, in Proc. of the Watershed Management Symposium, pp. 191.

Lowrance, R., Vellidis, G., Wauchope, R.D., Gay, P. and Bosch, D.D. (1997). Herbicide transport in a managed riparian forest buffer system. Trans. ASAE, 40(4), 1047-1057.

Lowrance, R., Williams, R.G., Inamdar, S.P., Bosch, D.D. and Sheridan, J.M. (2001). Evaluation of coastal plain conservation buffers using the riparian ecosystem management model. J. Am. Water Resour. Assoc., 37(6), 1445-1455.

Lunetta, R.S., Ediriwickrema, J., Iiames, J., Johnson, D.M., Lyon, J.G., Mckerrow, A. and Pilant, A. (2003). A quantitative assessment of a combined spectral and GIS rule-based land-cover classification in the neuse river basin of North Carolina. Photogramm. Eng. Remote Sens., 69(3), 299-310.

Marion, J. and Cole, D. (1996). Spatial and temporal variation in soil and vegetation impacts on campsites. Ecol. Appl., 6(2), 520-530.

Martin, T.L., Kaushik, N.K., Trevors, J.T. and Whiteley, H.R. (1999). Review: Denitrification in temperate climate riparian zones. $\mathrm{Wa}$ ter, Air Soil Pollut., 111(1), 171-186.

Maser, C. and Trappe, J. (1984). The Seen and Unseen World of the Fallen Tree, Report PNW-164, US Department of Agriculture, 
Forest Service, Pacific Northwest Forest and Range Experiment Station, in cooperation with US Department of the Interior, Bureau of Land Management, Portland, OR, pp. 56.

Maser, C., Trappe, J. and Nussbaum, R. (1978). Fungal-small mammal interrelationships with emphasis on Oregon coniferous forests. Ecol., 59(4), 799-809.

Matero, J. (2004). Cost-effective measures for diffuse load abatement in forestry. Silva Fennica, 38(3), 333-345.

May, C. (1998). Salmonid habitat in urban streams of the Puget Sound lowlands, in Proc. of ASCE Wetlands Engineering River Restoration Conference, pp. 6.

May, C.W. and Horner, R.R. (2002). The limitations of mitigationbased stormwater management in the Pacific Northwest and the potential of a conservation strategy based on low-impact development principles, Global Solutions for Urban Drainage, pp. 1-16.

McClain, M. and Cossio, R. (2003). The use of riparian environments in the rural Peruvian Amazon. Source: Environ. Conserv., 30(3), 242-248.

Mcglynn, B.L. and Seibert, J. (2003). Distributed assessment of contributing area and riparian buffering along stream networks. $\mathrm{Am}$. Geophys. Union., 39(4), 21-27.

Meding, S.M., Morris, L.A., Hoover, C.M., Nutter, W.L. and Cabrera, M.L. (2001). Denitrification at a long-term forested land treatment system in the piedmont of Georgia. J. Environ. Qual., 30 (4), 1411-1420.

Michener, W., Blood, E., Bildstein, K., Brinson, M. and Gardner, L. (1997). Climate change, hurricanes and tropical storms, and rising sea level in coastal wetlands. Ecol. Appl., 7(3), 770-801.

Miltner, R.J., White, D. and Yoder, C. (2004). The biotic integrity of streams in urban and suburbanizing landscapes. Landscape $U r$ ban Plann., 69(1), 87-100.

Mitsch, W., Cronk, J., Wu, X., Nairn, R. and Hey, D. (1995). Phosphorus retention in constructed freshwater riparian marshes. Ecol. Appl., 5(3), 830-845.

Montas, H.J., Moran, L.B., Peters, C., Shipman, K., Ifft, T.H., Felton, G.K, and Shirmohammdi, A. (2000). GIS evaluation of riparian buffer impacts in a Maryland watershed, Engineering Solutions for a New Century, 2000 ASAE Annual International Meeting, Milwaukee, USA, 2, pp. 9277-9297.

Moore, R.D. and Wondzell, S. (2005). Physical hydrology and the effects of forest harvesting in the Pacific Northwest: A review. $J$. Am. Water Resour. Assoc., 41(4), 753-784.

Moring, J. and Lantz, R. (1975). The Alsea Watershed Study: Effects of Logging on the Aquatic Resources of Three Headwater Stream of the Alsea River, Oregon, Part I-Biological studies, Report No. 9, Oregon Department of Fish and Wildlife, Fish Division, Portland.

Nagler, P., Glenn, E., Hursh, K., Curtis, C. and Huete, A. (2005). Predicting riparian evapotranspiration from MODIS vegetation indices and meteorological data. Remote Sens. Environ., 94(1), 17-30.

Naiman, R., Decamps, H. and Pollock, M. (1993). The role of riparian corridors in maintaining regional biodiversity. Ecol. Appl., $3(2), 209-212$.

Nerbonne, B.A. and Vondracek, B. (2001). Effects of local land use on physical habitat, benthic macroinvertebrates, and fish in the whitewater river, Minnesota, USA. Environ. Manage., 28(1), 87-99.

Nikolaidis, N.P., Shen, H., Heng, H., Hu, H.L. and Clausen, J.C. (1993). Movement of nitrogen through an agricultural riparian zone: Distributed modeling. Water Sci. Technol., 28(3-5), 613623.

Oelbermann, M. and Gordon, A.M. (2000). Quantity and quality of autumnal litterfall into a rehabilitated agricultural stream. $J$. Environ. Qual., 29(2), 603-611.
Osterkamp, W. and Hupp, C. (1984). Geomorphic and vegetative characteristics along three northern Virginia streams. Geol. Soc. Am. Bull., 95, 1093-1101.

Parsons, J., Thomas, D. and Huffman, R. (2001). Agricultural nonpoint source water quality models: Their use and application, Southern Cooperative Series Bulletin \#398. http://www3.bae.nc su.edu/Regional-Bulletins/Modeling-Bulletin/ModelSummaryT ables.html.

Parsons, J.E., Gilliam, J.W., Neal, W. and Mikkelsen, R.L. (1997). Modeling offsite water quality impacts of land applications of swine waste effluent. Am. Soc.Agric. Eng., 2, 14.

Payne, N., Helson, B., Sundaram, K. and Fleming, R. (1988). Estimating buffer zone widths for pesticide applications. Pestic. Sci., 21.147-161.

Petersen, R.C.Jr., Madsen, B.L., Wilzbach, M.A., Magadza, C.H.D., Paarlberg, A., Kullberg, A. and Cummins, K.W. (1987). Stream management: Emerging global similarities. Ambio., 16(4), 166179.

Phillips, J.D. (1989). An evaluation of the factors determining the effectiveness of water-quality buffer zones. J. Hydrol., 107(1-4), 133-145.

Phillips, J.D. (1989). Evaluation of North Carolinas estuarine shoreline area of environmental concern from a water-quality perspective. Coast. Manage., 17(2), 102-117.

Phillips, J.D. (1989). Nonpoint source pollution control effectiveness of riparian forests along a coastal plain river. J. Hydrol., 110 (3-4), 221-237.

Pinay, G., Roques, L. and Fabre, A. (1993). Spatial and temporal patterns of denitrification in a riparian forest. J. Appl. Ecol., 30(4), 581-591.

Poole, G.C. and Berman, C.H. (2001). An ecological perspective on in-stream temperature: natural heat dynamics and mechanisms of human-caused thermal degradation. Environ. Manage., 27(6), 787-802

Potter, K.M., Cubbage, F.W., Blank, G.B. and Schaberg, R.H. (2004). A watershed-scale model for predicting nonpoint pollution risk in North Carolina. Environ. Manage., 34(1), 62-74.

Puckett, L.J., Cowdery, T.K., Mcmahon, P.B., Tornes, L.H. and Stoner, J.D. (2002). Using chemical, hydrologic, and age dating analysis to delineate redox processes and flow paths in the riparian zone of a glacial outwash aquifer-stream system. Water Resour. Res., 38(8), 91-920.

Qiu, Z. and Prato, T. (1998). Economic evaluation of riparian buffers in an agricultural watershed. J. Am. Water Resour. Assoc., 34(4), $877-890$

Qiu, Z. and Prato, T. (2001). Physical determinants of economic value of riparian buffers in an agricultural watershed. $J$. Am. Water Resour. Assoc., 37(2), 295-303.

Rapport, D, Regier, H. and Hutchinson, T. (1985). Ecosystem behaviour under stress. Am. Nat., 125(5), 617-640.

Reeves, L.H. (2004). Comparing the value of leave-tree buffers with a forest excise tax credit in Washington state. Western J. Appl. For., 19(3), 165-170.

Reid, R., Kruska, R., Muthui, N., Taye, A., Wotton, S., Wilson, C. and Mulatu, W. (1997). Impacts of tsetse control and land-use on vegetative structure and tree species composition in southwestern Ethiopia. J. Appl. Ecol., 34(3), 731-747.

Reungsan, A., Moorman, T.B. and Kanwar, R.S. (2001). Transport and fate of atrazine in midwestern riparian buffer strips. J. Am. Water Res. Assoc., 37(6), 1681-1692.

Robinson, J.L., Rickman, J.D., Townsend, L.R. and Moffitt, D.C. (1997). Riparian forest buffers: NRCS standard, the research basis and interpretation required for implementation. $\mathrm{Am}$. Soc. $\mathrm{Ag}$ ric. Eng., 3, 7.

Saab, V. (1999). Importance of spatial scale to habitat use by breeding birds in riparian forests: A hierarchical analysis. Ecol. Appl., 
9(1), 135-151.

Sala, A., Smith, S. and Devitt, D. (1996). Water use by Tamarix Ramosissima and associated phreatophytes in a Mojave Desert floodplain. Ecol. Appl., 6(3), 888-898.

Scott, M., Auble, G. and Friedman, J. (1997). Flood dependency of cottonwood establishment along the Missouri River, Montana, USA. Ecol. Appl., 7(2), 677-690.

Scott, M.C., Helfman, G.S., Mctammany, M.E., Benfield, E.F., and Bolstad, P.V. (2002). Multiscale influences on physical and chemical stream conditions across blue ridge landscapes. $\mathrm{J}$. Am. Water Resour. Assoc., 38(5), 1379-1392.

Sedell, J. and Swanson, F. (1982). Ecological characteristics of streams in old-growth forests of the Pacific Northwest, in W.R. Meehan, T.R. Merrell-Jr and T.A. Hanley (Eds.), Proc. of the fish and wildlife relationships in old-growth forests symposium, Juneau, Alaska, Am. Inst. Fish. Res. Biol., 425, 9-16,

Sedell, J., Richey, J. and Swanson, F. (1989). The river continuum concept: A basis for the expected ecosystem behavior of very large rivers?, in D.P. Dodge (Ed.), Proc. of the International Large River Symposium, Can. Spec. Publ. Fish. Aquat. Sci., 106, 49-55.

Shannon, R.D., Filte Iii, O.P., Schnabel, R.R. and Parizek, R.R. (2000). Denitrification in a forested riparian buffer receiving nitrified wastewater effluent, Engineering Solutions for A New Century, 2000 ASAE Annual International Meeting, Milwaukee, USA, 2.

Sharitz, R., Boring, L., Lear, D. and Pinder, J. (1992). Integrating ecological concepts with natural resource management of southern forests. Ecol. Applic., 2(3), 226-237.

Sheridan, J.M., Lowrance, R. and Bosch, D.D. (1999). Management effects on runoff and sediment transport in riparian forest buffers. Trans. ASAE, 42(1), 55-64.

Shirley, S. (2004). The influence of habitat diversity and structure on bird use of riparian buffer strips in coastal forest of British Columbia, Canada. Can. J. For. Res., 34(7), 1499-1510.

Simpkins, W.W., Wineland, T.R., Andress, R.J., Johnston, D.A., Caron, G.C., Isenhart, T.M. and Schultz, R.C. (2002). Hydrogeological constraints on riparian buffers for reduction of diffuse pollution: examples from the bear creek watershed in Iowa, USA. Water Sci. Technol., 45(9), 61-68.

Skagen, S., Melcher, C., Howe, W. and Knopf, F. (1998). Comparative use of riparian corridors and oases by migrating birds in southeast Arizona. Conserv. Biol., 12(4), 896-909.

Smith, S., Wellington, A., Nachlinger, J. and Fox, C. (1991). Functional responses of riparian vegetation to streamflow diversion in the eastern Sierra Nevada. Ecol. Appl., 1(1), 89-97.

Snodgrass, J. (1997). Temporal and spatial dynamics of beaver-created patches as influenced by management practices in a southeastern North American landscape. J. Appl. Ecol., 34(4), 10431056.

Soranno, P., Hubler, S., Carpenter, S. and Lathrop, R. (1996). Phosphorus loads to surface waters: A simple model to account for spatia pattern of land use. Ecol. Appl., 6(3), 865-878.

Spruill, T.B. (2000). Statistical evaluation of effects of riparian buffers on nitrate and ground water quality. J. Environ. Qual., 29(5), $1523-1538$

Spruill, T.B. (2004). Effectiveness of riparian buffers in controlling ground-water discharge of nitrate to streams in selected hydrogeologic settings of he North Carolina coastal plain. Water Sci. Technol., 49(3), 63-70.

Stevens, L., Schmidt, J., Ayers, T. and Brown, B. (1995). Flow regulation, geomorphology, and Colorado River marsh development in the Grand Canyon, Arizona. Ecol. Appl., 5(4), 1025-
1039.

Stewart, D. and Samways, M. (1998). Conserving dragonfly (odonata) assemblages relative to river dynamics in an African savanna game reserve. Conserv. Biol., 12(3), 683-692.

Stewart, J.S., Wang, L., Lyons, J., Horwatich, J.A., and Bannerman, R. (2001). Influences of watershed, riparian-corridor, and reachscale characteristics on aquatic biota in agricultural watersheds. J. Am. Water Resour. Assoc., 37(6), 1475-1487.

Stohlgren, T., Schell, L. and Vanden Heuvel, B. (1999). How grazing and soil wuality affect native and exotic plant diversity in Rocky Mountain grasslands. Ecol. Appl., 9(1), 45-64.

Stohlgren, T., Chong, G., Kalkhan, M. and Schell, L. (1997). Multiscale sampling of plant diversity: Effects of minimum mapping unit size. Ecol. Appl., 7(3), 1064-1074.

Stone, K.C., Gerwig, B.K., Williams, R.G., Watts, D.W. and Novak, J.M. (2001). Using GLEAMS and REMM to estimate nutrient movement from a spray field and through a riparian forest. Trans. Am. Soc. Agric. Eng., 44(3), 505-512.

Stromberg, J., Tiller, R. and Richter, B. (1996). Effects of groundwater decline on riparian vegetation of semiarid regions: The San Pedro, Arizona. Ecol. Appl., 6(1), 113-131.

Stromberg, J., Wilkins, S. and Tress, J. (1993). Vegetation-hydrology models: Implications for management of prosopis velutina (velvet mesquite) riparian ecosystems. Ecol. Appl., 3(2), 307-314.

Swanson, F. and Lienkaemper, G. (1978). Physical Consequences of Large Organic Debris in Pacific Northwest Streams, US Department of Agriculture, Forest Service, Pacific Northwest Forest and Range Experiment Station, Portland, pp. 12.

Swanson, F., Gregory, S., Sedell, J. and Campbell, A. (1982b). Landwater interactions: The riparian zone, in R.L. Edmonds (Ed.), Analysis of Coniferous Forest Ecosystems in the Western United States, Hutchinson Ross Pub., Stroudsburg, PA, pp. 267-291.

Thompson, B.E. (2001). Federal perspectives on Illinois river restoration efforts, in Proc. of the 2001 Wetlands Engineering and River Restoration Conference, pp. 85-92.

Thornton, K.W., Holbrook, S.P., Stolte, K.L. and Landy, R.B. (2000). Effects of forest management practices on mid-atlantic streams. Environ. Monit. Assess., 63(1), 31-41.

Toner, M. and Keddy, P. (1997). River hydrology and riparian wetlands: A predictive model for ecological assembly. Ecol. Appl., 7(1), 236-246.

Torgerson, C., Price, D., Li, H. and McIntosh, B. (1999). Multiscale thermal refugia and stream habitat associations of chinook salmon in northeastern Oregon. Ecol. Appl., 9(1), 301-319.

Tufford, D.L., Mckellar, H.N.Jr. and Hussey, J.R. (1998). In-stream nonpoint source nutrient prediction with land-use proximity and seasonality. J. Environ. Qual., 27(1), 100-110.

USDA (1993). Forest Ecosystem Management: An Ecological, Economic, and Social Assessment, USDA Forest Service and Other Agencies, Portland, OR.

Vache, K.B., Eilers, J.M. and Santelmann, M.V. (2002). Water quality modeling of alternative agricultural scenarios in the US corn belt. J. Am.Water Resour. Assoc., 38(3), 773-787.

Vannote, R., Minshall, G., Cummins, Sedell, J. and Cushing, C. (1980). The river continuum concept. Can. J. Fish. Aquat. Sci., 37, 130-137.

Velilidis, G. and Lowrance, R. (2004). Riparian forest buffers. Eng. Technol. Sustain. World, 11(10), 7-8.

Vidon, P.G.F. and Hill, A.R. (2004). Landscape controls on nitrate removal in stream riparian zones. Water Resour. Res., 40(3), W032011-W0320114.

Von Waldow, H., Gainham, C., Landriault, L., Price, J.S. and Stone, M. (2002). Distribution and movement of nitrate in soils from 
snowpack in a stream riparian zone, Waterloo, Ontario. Can. Water Resour. J., 27(2), 175-189.

Walsh, A. and Harris, S. (1996). Foraging habitat preferences of vespertilionid bats in Britain. J. Appl. Ecol., 33(3), 508-518.

Welsh, H. and Ollivier, L. (1998). Stream amphibians as indicators of ecosystem stress: A case study from California's Redwoods. Ecol. Appl., 8(4), 1118-1132.

Weng, P., Sanchez-Perez, J.M., Sauvage, S., Vervier, P. and Giraud, F. (2003). Assessment of the quantitative and qualitative buffer function of an alluvial wetland: hydrological modeling of a large floodplain (Garonne River, France). Hydrol. Process., 17(12), 2375-2392.

Wenger, S. (1999). A Review of the Scientific Literature on Riparian Buffer Width, Extent and Vegetation, Office of Public Service and Outreach Institute of Ecology, University of Georgia.

Weston, D.G. (1995). Effectiveness of buffer zones in conifer-afforested catchments. J. Chartered Inst. Water Environ. Manage., 9(4), 396-404.

Wigington-Jr., P.J., Griffith, S.M., Field, J.A., Baham, J.E., Horwath, W.R., Owen, J., Davis, J.H., Rain, S.C. and Steiner, J.J. (2003). Nitrate removal effectiveness of a riparian buffer along a small agricultural stream in western Oregon. J. Environ. Qual., 32(1), 162-170.

Wilzbach, M., Harvey, B., White, J. and Nakamoto, R. (2005). Effects of riparian canopy openings and salmon carcass addition on abundance and growth of resident salmonids. Can. J. Fish. Aquat. Sci., 62(1), 58-67.

Wynn, T.M., Mostaghimi, S., Burger, J.A., Harpold, A.A., Henderson, M.B. and Henry, L. (2004). Variation in root density along stream banks. J. Environ.l Qual., 33(6), 2030.
Xiang, W.N. (1993a). A GIS method for riparian water quality buffer generation. Int. J. Geogr. Inform. Syst., 7(1), 57-70.

Xiang, W.N. (1993b). Application of A GIS-based stream buffer generation model to environmental policy evaluation. Environ. Manage.: Int. J. Decis. Makers, Sci., Environ. Auditors, 17(6), 817-827.

Xiang, W.N. (1996). GIS-based riparian buffer analysis: injecting geographic information into landscape planning. Landscape Urban Plann. (Amsterdam), 34(1), 1-10.

Xiang, W.N. (1998). Assessment of the buffer-induced setback effects on riparian scenic quality by digital tools. Environ. Plann. B: Plann. Design, (25)6, 881-894.

Young, R. and Huryn, A. (1999). Effects of land use on stream metabolism and organic matter turnover. Ecol. Appl., 9(4), 13591376.

Zhang, Q., Mankin, K.R. and Erickson, L.E. (2000). Effectiveness of vegetative filter strips in reducing nutrients and fecal microorganisms from feedlot runoff, Engineering Solutions for a New Century, 2000 ASAE Annual Intenational Meeting, Milwaukee, USA, 2.

Zimmerman, J.K.H., Vondracek, B. and Westra, J. (2003). Agricultural land use effects on sediment loading and fish assemblages in two Minnesota (USA) watersheds. Environ. Manage., 32(1), 93-105.

Zorbist, K., Andreu, M., Hinkley, T., Gehringer, K. and Hedman, C. (2005). Technical report d: Management templates for increased biodiversity and economics in intensively managed loblolly pine plantations, Final technical report to the National Comission on Science for Sustainable Forestry (NCSSF). http://www.ruraltech. org/pubs/working/ncssf/tecd/index.asp. 